\title{
Novel Feed Including Olive Oil Mill Wastewater Bioactive Compounds Enhanced the Redox Status of Lambs
}

\author{
SOTIRIA MAKRI ${ }^{1}$, IOANNIS KAFANTARIS ${ }^{1}$, SALOMI SAVVA ${ }^{1}$, POLYXENI NTANOU ${ }^{1,2}$, \\ DIMITRIOS STAGOS $^{1}$, IOANNIS ARGYROULIS ${ }^{1}$, BASILIKI KOTSAMPASI ${ }^{3}$, \\ VLADIMIROS CHRISTODOULOU ${ }^{3}$, KONSTANTINOS GERASOPOULOS $^{1,4}$, \\ KONSTANTINOS PETROTOS ${ }^{4}$, DIMITRIOS KOMIOTIS ${ }^{1}$ and DEMETRIOS KOURETAS ${ }^{1}$ \\ ${ }^{1}$ Department of Biochemistry and Biotechnology, University of Thessaly, Larissa, Greece; \\ ${ }^{2}$ Department of Pharmacology, Aristotle University of Thessaloniki, Thessaloniki, Greece; \\ ${ }^{3}$ Research Institute of Animal Science/Hellenic Agricultural Organization Demeter, Giannitsa, Greece; \\ ${ }^{4}$ Department of Biosystem Engineering, Technical Education Institute of Thessaly, Larissa, Greece
}

\begin{abstract}
Background/Aim: The aim of the present study was to investigate the antioxidant effects of a feed supplemented with polyphenolic additives from olive mill wastewater $(\mathrm{OMW})$ on lambs. Materials and Methods: Lambs received breast milk until the postnatal period, and then they were divided into two groups and received control and $O M W$ feed for 55 days. Redox biomarkers were measured in blood and tissues at days 15, 42 and 70 after feeding. Results: Feed supplemented with OMW reduced thiobarbituric acid reactive species and protein carbonyls and increased total antioxidant capacity, glutathione and catalase activity in both blood and tissues. Conclusion: The administration of OMW-containing feed reinforced the antioxidant defense of lambs, which may improve their wellbeing and productivity. Additionally, this exploitation of OMW may solve problems of environmental pollution in areas with olive oil industries.
\end{abstract}

Mediterranean countries are responsible for $95 \%$ of worldwide olive oil production (1). In Greece, the extraction and manufacture of olive oil is carried out in about 2,400 small scale agro-industrial units scattered throughout the country. These processes produce two waste streams: olive

This article is freely accessible online.

Correspondence to: Demetrios Kouretas, Department of Biochemistry and Biotechnology, University of Thessaly, Viopolis, Mezourlo, Larissa 41500, Greece. Tel: +30 2410565277, Fax: +30 2410565293, e-mail: dkouret@uth.gr

Key Words: Oxidative stress markers, olive mill wastewater, lambs, polyphenols. mill residual solids and olive mill wastewaters (OMW). OMW are formed from the water content of the fruit itself and the water used to wash and process them, and amounts to $0.5-3.25 \mathrm{~m}^{3}$ per $1,000 \mathrm{~kg}$ of olives (2). Typically, the composition of OMW is water, organics and mineral salts. OMW comprises large amounts of organic (e.g. fats, lipids, polyphenols), inorganic constituents and water; a part of the organic fraction is composed of phenols (1). These compounds are responsible for its black color, toxicity, phytotoxicity and antibacterial properties (3).

It is estimated that around 30 million cubic meters of OMW are generated annually in the Mediterranean area (4). Disposal of OMW causes serious environmental problems, such as soil contamination, water body pollution, underground seepage and odor (5). The environmental problems and potential hazards caused by OMW have prompted many countries to limit its discharge. Varied new technologies for reducing its pollutant power (e.g. physicochemical and biological methods), have been investigated in recent years (1). Technologies such as advanced oxidative processes have been proposed, but these are characterized by high operational costs and frequently require complex maintenance and availability of experienced personnel (6). Thus, an environmentally safe and costeffective treatment of OMW has not yet been found (7).

Oleuropein, tyrosol and hydroxytyrosol are the main phenolic compounds found in OMW. Other phenolic compounds that are found in olive oil are caffeic acid, vanillic acid, coumaric acid, ferulic acid, gallic acid, hydroxybenzoic acid, kaempherol, apigenin and quercetin (8, 9). Despite toxic effects exhibited at high concentrations, these polyphenols also exhibit antioxidant activity. Therefore, the polyphenolic content of OMW could represent a source of antioxidants in different fields, such as nutrition, 
pharmaceutical and cosmetic industries, while reducing the environmental pollution causing by OMW (10).

In recent years, there is evidence that bioactive compounds present in foods possess properties which give them the ability to protect against chronic diseases (11-13). Studies have shown that in farm animals, oxidative stress is involved in various pathological situations, directly related to animal welfare (14). For example, common diseases such as pneumonia (15), enteritis (16) and septicemia in pigs (17) are caused by disorders in antioxidant homeostasis. The administration of antioxidants can protect animals from these diseases or reduce their clinical symptoms (18). In addition, studies have shown that animals at an early age have a low antioxidant system compared to adults $(19,20)$, and so it is more important to administer antioxidants to young animals for disease protection.

Polyphenols contribute significantly to antioxidant defense of animals by increasing the antioxidant levels of endogenous molecules and enzymes, while enhancing the immune system (21). In particular, polyphenols from OMW have antioxidant properties which are related to prevention of diseases caused by oxidative stress (22-25). According to Paiva-Martins et al. (26), polyphenols of olive oil protected human erythrocytes from oxidative damage. In particular, 3hydroxytyrosol, an olive oil polyphenol, plays a remarkable role against reactive oxygen species (ROS) that cause cellular damage. Studies in animals and humans have shown that polyphenol components of OMW exhibit important biological activities that can prevent oxidative stressassociated diseases $(13,27)$. Recent studies of our research group showed broiler chickens and piglets given feed supplemented with OMW exhibited an increased antioxidant capacity in blood and tissues $(10,28)$.

Thus, the aim of present study was to exploit OMW byproducts to produce a biofunctional feed of high added value for lambs in order to enhance the animal's antioxidant defense, welfare and productivity. Moreover, exploitation of OMW to develop biofunctional feeds may reduce associated environmental problems.

\section{Materials and Methods}

Olive mill wastewater. Olive mill wastewater (OMW) was obtained directly from a local olive oil mill in Larissa prefecture (Greece), without any further processing. OMW was characterized by high organic load (chemical oxygen demand: 45-100 g/l, biological oxygen demand: $25-50 \mathrm{~g} / \mathrm{l}), \mathrm{pH}$ : $4.6-5.2$, total solids $(39.4 \pm 1.8 \mathrm{~g} / \mathrm{l})$, water content: $960.6 \pm 19 \mathrm{~g} / \mathrm{l}$, significant concentrations of magnesium, potassium, phosphate salts and organic compounds $(29,30)$.

Silage preparation. OMW was added to lamb feed as silage. The silage contained corn, OMW, water and lactic acid bacteria. Based on previous studies, the proportion of the ingredients was such that the silage contained $60 \%$ solids and $40 \%$ liquids $(10,28)$. Standard commercial formulation (11CFT; Pioneer, Buxtehude, Germany) of lactic bacteria was used for the lactic fermentation of corn and the preparation of corn silage. The lactic bacteria had been dissolved in water $(10 \% \mathrm{w} / \mathrm{v})$ by stirring and warmed at $40^{\circ} \mathrm{C}$ in order to be activated prior to mixing with corn. After activation, lactic bacteria were mixed with corn ( $1 \mathrm{~g}$ of bacteria with $100 \mathrm{~kg}$ of corn). For producing the silage, the mixture of lactic bacteria and corn was placed in special airtight-seal plastic bags and was fermented for 34 weeks. To prevent the bags from rupturing due to the inflation caused by the carbon dioxide production during fermentation, the material was repackaged in new plastic bags every 2 to 3 days. Finally, the resulting silage, containing $52.5 \%$ solids, $7.5 \%$ OMW and $40 \%$ water, was mixed with other ingredients to make the final lamb feed. The final feed composition before and after weaning is presented in Table I. Milk that was contained in diets before weaning was replaced by wheat and sunflower meal in the diets after weaning (Table I).

Animals and diets. The breeding of lambs held at the Research Institute of Animal Science (Paralimni Giannitson, Greece/Hellenic Agricultural Organization - Demeter) by applying diet in normal living and development conditions. Both living conditions and the way that the lambs were sacrificed for blood and tissue collections were performed according to EU Directive 2010/63/EU for animal experiments.

The experiment was reviewed and approved by the Institutional Review Board of the University of Thessaly (no. 89/10.12.2014). Twenty-eight young male lambs of Chios breed were selected from the flock of the Animal Research Institute. When the feeding started at 15 days after birth, the lambs weighed on average $7.99 \pm 1.80 \mathrm{~kg}$ and were divided into two homogeneous groups (12 lambs per group) as follows: (a) Lambs fed with standard ration (control group) and (b) lambs fed with ration containing silage with OMW (OMW group) for 55 days (i.e. from 15 to 70 days) (Table I). During the age of weaning (i.e. from 15 to 42 days), lambs remained along with their ewes in two separate stalls (one for each group) for breastfeeding and also had access to feed, either to the standard or to experimental feed, alfalfa hay and water for $a d$ libitum consumption. The ewes were fed with standard feed without access to the ration supplemented with OMW and they were separated from the lambs at day 42 (Table I). During the experimental trial, lambs were weighed individually weekly and average daily gain (ADG, g/day) was calculated.

Determination of total polyphenolic content (TPC) of feed rations. The TPC of control ration and ration supplemented with OMW was determined using Folin Ciocalteu reagent, as described previously (31). The two rations were originally in a solid state and were liquefied as described previously (32). Briefly, $20 \mu \mathrm{l}$ of sample was added to a tube containing $1 \mathrm{ml}$ of deionized water $\left(\mathrm{dH}_{2} \mathrm{O}\right)$. The total of $100 \mu \mathrm{l}$ Folin-Ciocalteu reagent was added to the reaction mixture, followed by incubation for $3 \mathrm{~min}$ at room temperature. Subsequently, $280 \mu \mathrm{l}$ of $25 \% \mathrm{w} / \mathrm{v}$ sodium carbonate solution and $600 \mu \mathrm{l}$ of $\mathrm{dH}_{2} \mathrm{O}$ were added to the mixture. Following $1 \mathrm{~h}$ of incubation at room temperature in the dark, the absorbance was measured at $765 \mathrm{~nm}$ against a blank containing Folin-Ciocalteu reagent and $\mathrm{dH}_{2} \mathrm{O}$ without the sample. The measurement of absorbance was conducted on a Hitachi U-1900 radio beam spectrophotometer (Hitachi, Tokyo, Japan). The optical density of the sample (20 $\mu \mathrm{l})$ in $25 \% \mathrm{w} / \mathrm{v}$ solution of sodium carbonate $(280 \mu \mathrm{l})$ and $\mathrm{dH}_{2} \mathrm{O}(1.7 \mathrm{ml})$ at $765 \mathrm{~nm}$ was also 
Table I. Ingredients and nutrient composition (\% w/w) of experimental and control diets for lambs before and after weaning.

\begin{tabular}{lccccc}
\hline & \multicolumn{2}{c}{ Before weaning } & & \multicolumn{2}{c}{ After weaning } \\
\cline { 2 - 3 } \cline { 5 - 6 } Ingredients & $\begin{array}{c}\text { Control } \\
\text { group }\end{array}$ & $\begin{array}{c}\text { OMW } \\
\text { group }\end{array}$ & & $\begin{array}{c}\text { Control OMW } \\
\text { group }\end{array}$ & group \\
\hline Corn silage & 45.0 & 45.0 & & 45.0 & 45.0 \\
Wheat bran & 9.0 & 9.0 & & 15.0 & 15.0 \\
Wheat meal & 0 & 0 & & 13.0 & 13.0 \\
Soybean meal 44\% CP & 21.0 & 21.0 & & 18.0 & 18.0 \\
Milk replacer & 20.0 & 20.0 & & 0 & 0 \\
Vitamin and mineral premix $(2.5 \%)$ & 2.5 & 2.5 & & 2.5 & 2.5 \\
Sunflower meal & 0 & 0 & & 4.0 & 4.0 \\
Salt & 0.5 & 0.5 & & 0.5 & 0.5 \\
Limestone & 1.2 & 1.2 & & 1.2 & 1.2 \\
Monocalcium phosphate & 0.8 & 0.8 & & 0.8 & 0.8 \\
\hline
\end{tabular}

aSilage contained $60 \%$ corn solids and $40 \%$ water in control feed, and $52.5 \%$ corn solids, $7.5 \%$ olive oil mill wastewater (OMW) and $40 \%$ water in the OMW group.

measured. The results are expressed as gallic acid equivalents using a standard curve prepared from authentic gallic acid (Sigma-Aldrich, Munich, Germany).

Determination of antioxidant activity of feed rations: 2,2-Diphenyl1-picrylhydrazyl (DPPH) radical-scavenging assay: The freeradical scavenging activity (RSC) of both control ration and ration supplemented with OMW was evaluated by $\mathrm{DPPH}^{\bullet}$ radical assay (33). Briefly, $1.0 \mathrm{ml}$ of freshly prepared methanolic solution of DPPH radical $(100 \mu \mathrm{M})$ was mixed with the tested samples at different concentrations. The contents were vigorously mixed, incubated at room temperature in the dark for $20 \mathrm{~min}$ and the absorbance was recorded at $517 \mathrm{~nm}$. The measurement was conducted on a Hitachi U-1900 ratio beam spectrophotometer (Hitachi). In each analysis, the tested sample alone in methanol was used as blank and DPPH alone in methanol as control.

The percentage RSC of the tested extracts was calculated using the following equation: $\operatorname{RSC}(\%)=\left[\left(\mathrm{A}_{\text {control }}-\mathrm{A}_{\text {sample }}\right) / \mathrm{A}_{\text {control }}\right] \times 100$

where $\mathrm{A}_{\text {control }}$ and $\mathrm{A}_{\text {sample }}$ were the absorbance values of the control and the tested samples, respectively. Moreover, in order to compare the radical-scavenging efficiency of the feeds, the $\mathrm{IC}_{50}$ value, i.e. the concentration leading to $50 \%$ scavenging of the DPPH radical was calculated from the graph plotted of percentage RSC against the extract concentration. All experiments were carried out in triplicate and at least in two separate occasions.

2,2'-Azinobis-(3-ethylbenzothiazoline-6-sulfonic acid) (ABTS $\left.{ }^{+\bullet}\right)$ radical-scavenging assay: $\mathrm{ABTS}^{\bullet+}$ radical-scavenging activity was measured as described previously with minor modifications (34). In brief, $\mathrm{ABTS}^{+\bullet}$ radicals were produced by mixing $2 \mathrm{mM}$ of ABTS with $30 \mu \mathrm{M}$ of $\mathrm{H}_{2} \mathrm{O}_{2}$ and $6 \mu \mathrm{M}$ of horseradish peroxidase (HRP) (SigmaAldrich) in $50 \mathrm{mM}$ phosphate-buffered saline (PBS, pH 7.5). Immediately following the addition of HRP, the contents were vigorously mixed, incubated at room temperature in the dark and the reaction was monitored at $730 \mathrm{~nm}$ until stable absorbance was obtained.
Table II. Total polyphenolic content (TPC) of the two experimental feed types before and after lamb weaning. TPC is expressed as gallic acid equivalents, as measured by Folin-Ciocalteau assay. The results are presented as the mean \pm SEM.

\begin{tabular}{lll}
\hline TPC & Control group & OMW group \\
\hline Before weaning & $0.170 \pm 0.023$ & $0.348 \pm 0.019^{*}$ \\
After weaning & $0.138 \pm 0.028$ & $0.272 \pm 0.028^{*}$ \\
\hline
\end{tabular}

*Statistically significant different compared to the control $(p<0.05)$.

Subsequently, $10 \mu$ lof different control ration and ration supplemented with OMW at different concentration were added to the reaction mixture and the decrease in absorbance at $730 \mathrm{~nm}$ was determined. In each analysis, the sample extract alone containing $1 \mathrm{mM}$ of ABTS and $30 \mu \mathrm{M}$ of $\mathrm{H}_{2} \mathrm{O}_{2}$ in $50 \mathrm{mM}$ (PBS, pH 7.5) was used as a blank, while the $\mathrm{ABTS}^{\bullet+}$ radical solution alone with $10 \mu \mathrm{l}$ water was used as a control. The percentage inhibition and the $\mathrm{IC}_{50}$ values were determined as described above for the DPPH method. All analyses were carried out in triplicate and on at least two separate occasions.

Blood and tissue collection. Blood and tissues from 28 lambs were collected at three different time-points, at 15, 42 and 70 days after birth. At day 15, blood samples were collected from four lambs, in order to determine the redox status of lambs at a very young age before the administration of ration, at day 42 from 12 lambs (i.e. six lambs from each group) and at day 70 from 12 lambs (i.e. six lambs from each group). For blood collection, $4 \mathrm{ml}$ of blood were collected from the jugular vein and placed in vacutainer tubes with ethylenediamine tetraacetic acid (EDTA). The isolation of plasma and red blood cell lysate (RBCL) and the determination of hemoglobin concentration were performed as described previously (21).

At day 15, tissues were collected from four lambs in total (lambs were divided into two homogeneous groups at 15 days after birth when the feeding started), in order to determine their redox status at an early age before the feed administration. At day 42 , tissues were collected from 12 lambs (i.e. six lambs from each group) and finally, at day 70 from 12 lambs (i.e. six lambs from control and six lambs from the OMW group). For tissue collection, lambs were transported to a slaughterhouse and were immediately stunned prior to slaughtering in order to minimize suffering. All relevant procedures were executed by specialized staff according to industryaccepted procedures. Five tissues from vital organs, namely the heart, liver, brain, spleen and quadriceps muscle, were removed as quickly as possible, placed into tubes and snap-frozen in liquid nitrogen. In preparation for biochemical analysis, tissues samples were initially ground using a mortar and pestle under liquid nitrogen. The homogenization process was carried out as described previously (21). Plasma, RBCL and tissues were stored at $-80^{\circ} \mathrm{C}$ until biochemical analysis.

Determination of oxidative stress biomarkers. Reduced glutathione (GSH) was measured according to the method of Reddy et al. (35) In this assay, proteins in the erythrocyte lysate were precipitated twice with 5\% trichloroacetic acid (TCA) in order to eliminate protein-linked -SH groups. Briefly, $20 \mu \mathrm{l}$ of erythrocyte lysate or 
tissue homogenate (diluted 1:2) treated with 5\% TCA was mixed with $660 \mu \mathrm{l}$ of $67 \mathrm{mmol} / \mathrm{l}$ sodium potassium phosphate ( $\mathrm{pH} 8.0)$ and $330 \mu \mathrm{l}$ of $1 \mathrm{mmol} / \mathrm{l}$ 5,5'-dithiobis-2 nitrobenzoate. Samples were incubated in the dark at room temperature for $10 \mathrm{~min}$ and the absorbance was read at $412 \mathrm{~nm}$. The GSH concentration was calculated on the basis of calibration curve made using commercial standards (Sigma-Aldrich, Munich, Germany).

Catalase activity was determined in erythrocyte lysate using the method of Aebi (36). Briefly, $4 \mu \mathrm{l}$ of erythrocyte lysate (diluted $1: 10$ ) or $40 \mu \mathrm{l}$ of tissue homogenate (diluted 1:2) were added to 2991 or $2955 \mu \mathrm{l}$, respectively, of $67 \mathrm{mmol} / 1$ sodium potassium phosphate ( $\mathrm{pH} \mathrm{7.4)} \mathrm{and} \mathrm{samples} \mathrm{were} \mathrm{incubated} \mathrm{at} 37^{\circ} \mathrm{C}$ for $10 \mathrm{~min}$. A total of $5 \mu \mathrm{l}$ of $30 \%$ hydrogen peroxide $\left(\mathrm{H}_{2} \mathrm{O}_{2}\right)$ were added to the samples, and the change in absorbance was immediately read at 240 $\mathrm{nm}$ for 2 minutes. Calculation of catalase activity was based on the molar extinction coefficient of $\mathrm{H}_{2} \mathrm{O}_{2}\left(43.6 \mathrm{M}^{-1} \mathrm{~cm}^{-1}\right)$.

Protein carbonyl determination was based on the method of Patsoukis et al. (37) In this assay, $50 \mu$ of $20 \%$ TCA was added to $50 \mu \mathrm{l}$ of plasma or tissues homogenate (diluted 1:2), and this mixture was incubated in an ice-bath for $15 \mathrm{~min}$ and then centrifuged $(15,000$ $\times g, 5 \mathrm{~min}, 4^{\circ} \mathrm{C}$ ). The supernatant was discarded, and $500 \mu \mathrm{l}$ of 10 $\mathrm{mmol} / \mathrm{l}$ 2,4-dinitrophenylhydrazine (in $2.5 \mathrm{~N} \mathrm{HCl}$ ) per sample (500 $\mu \mathrm{l}$ of $2.5 \mathrm{~N} \mathrm{HCl}$ for the blank) was added to the pellet. The samples were incubated in the dark at room temperature for $1 \mathrm{~h}$ with intermittent vortexing every $15 \mathrm{~min}$ and were centrifuged (at 15,000 $\times g$ for 5 min at $4^{\circ} \mathrm{C}$ ). Proteins were then precipitated with $10 \%$ TCA and washed three times with ethanol-ethyl acetate $(1: 1 \mathrm{v} / \mathrm{v})$. The supernatant was discarded, and $1 \mathrm{ml}$ of $5 \mathrm{~mol} / \mathrm{L}$ urea $(\mathrm{pH} 2.3$ ) was added, vortexed and incubated at $37{ }^{\circ} \mathrm{C}$ for $15 \mathrm{~min}$. The samples were centrifuged (at $15,000 \times g$ for $5 \mathrm{~min}$ at $4^{\circ} \mathrm{C}$ ) and the absorbance was read at $375 \mathrm{~nm}$. Calculation of protein carbonyl concentration was based on the molar extinction coefficient of 2,4dinitrophenylhydrazine $\left(22 \times 10^{3} \mathrm{M}^{-1} \mathrm{~cm}^{-1}\right)$. Total protein was assayed using Bradford reagent (Sigma-Aldrich, Munich, Germany).

Thiobarbituric acid-reactive substances (TBARS) assay was used for the determination of lipid peroxidation. TBARS were determined according to a slightly modified assay of Keles et al. (38). In detail, $100 \mu \mathrm{l}$ of plasma or $50 \mu \mathrm{l}$ of tissue homogenate (diluted 1:2) was mixed with $500 \mu \mathrm{l}$ of $35 \%$ TCA and $500 \mu \mathrm{l}$ of Tris- $\mathrm{HCl}(200 \mathrm{mmol} / \mathrm{l} ; \mathrm{pH} \mathrm{7.4)}$, and incubated for $10 \mathrm{~min}$ at room temperature. One milliliter of $2 \mathrm{~mol} / \mathrm{N} \mathrm{Na}_{2} \mathrm{SO}_{4}$ and $55 \mathrm{mmol} / \mathrm{l}$ thiobarbituric acid solution was added, and the samples were incubated at $95{ }^{\circ} \mathrm{C}$ for $45 \mathrm{~min}$. The samples were cooled on ice for $5 \mathrm{~min}$, and were vortexed after $1 \mathrm{ml}$ of $70 \%$ TCA was added. The samples were centrifuged at $15000 \times g$ for $3 \mathrm{~min}$, and the absorbance of the supernatant was read at $530 \mathrm{~nm}$. A baseline shift in absorbance was taken into account by running a blank along with all samples during the measurement. TBARS are expressed in terms of malondialdehyde (MDA) equivalents. The molar coefficient of MDA is $155 \times 10^{3} \mathrm{~mol} / 1$.

Determination of total antioxidant capacity (TAC) was based on the method of Janaszewska and Bartosz, (39). Briefly, $20 \mu \mathrm{l}$ of plasma or $40 \mu \mathrm{l}$ tissue homogenate (diluted 1:10) were added to $480 \mu \mathrm{l}$ or $460 \mu \mathrm{l}$, respectively, of $10 \mathrm{mmol} / \mathrm{l}$ sodium potassium phosphate $(\mathrm{pH}$ 7.4 ) and $500 \mu \mathrm{l}$ of $0.1 \mathrm{mmol} / \mathrm{DPPH}$ free radical and samples were incubated in the dark for $60 \mathrm{~min}$ at room temperature. Samples were centrifuged for $3 \mathrm{~min}$ at $20000 \times \mathrm{g}$, and the absorbance was read at $520 \mathrm{~nm}$. TAC is presented as mmol of DPPH reduced to 2,2diphenyl-1-picrylhydrazine (DPPH:H) by antioxidants of plasma and tissue.

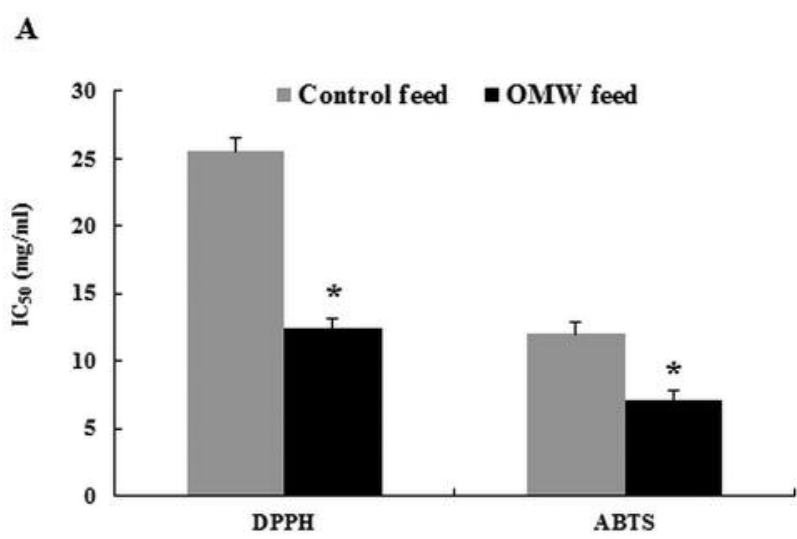

B

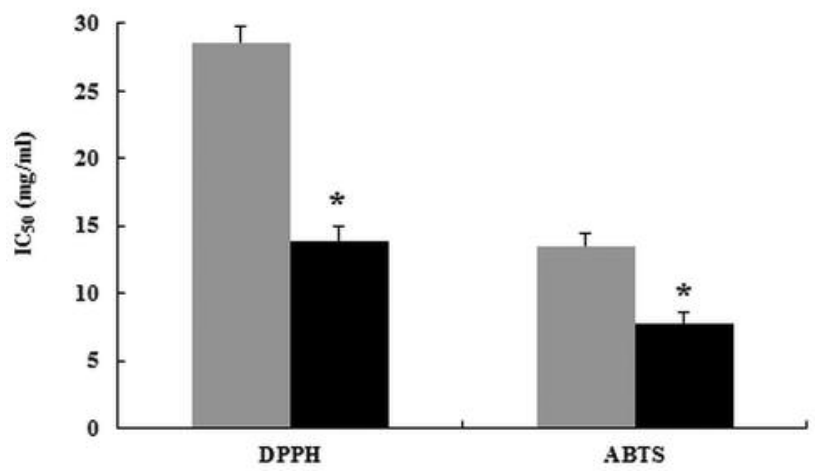

Figure 1. 2,2-Diphenyl-1-picrylhydrazyl (DPPH $\left.{ }^{*}\right)$ and 2,2'-Azinobis-(3ethylbenzothiazoline-6-sulfonic acid) $\left(A_{\left.B T S^{+}\right)}\right)$radical-scavenging capacity $(A)$ before and $(B)$ after weaning of standard (control) and experimental $(O M W)$ feed. * Significantly different from the control value $(p<0.05)$.

Each assay was performed in triplicate and within 3 months of blood and tissue collection. Samples were stored in multiple aliquots at $-80^{\circ} \mathrm{C}$, and thawed only once before analysis. All reagents were purchased from Sigma-Aldrich (Munich, Germany). All measurements were conducted on a Hitachi U-1900 ratio beam spectrophotometer (serial no. 2023-029; Hitachi, Tokyo, Japan).

Statistical analysis. Data were analyzed by one-way ANOVA. The level of statistical significance was set at $p<0.05$. All results are expressed as the mean \pm SEM. Data were analyzed using SPSS, version 13.0 (SPSS Inc., Chicago, IL, USA).

\section{Results}

Assessment of TPC of experimental feed. The results from the TPC assay indicated TPC was at least 2-fold higher in the feed supplemented with OMW, both before and after weaning, compared to the control group because of the inclusion of OMW in the feed (Table II). 


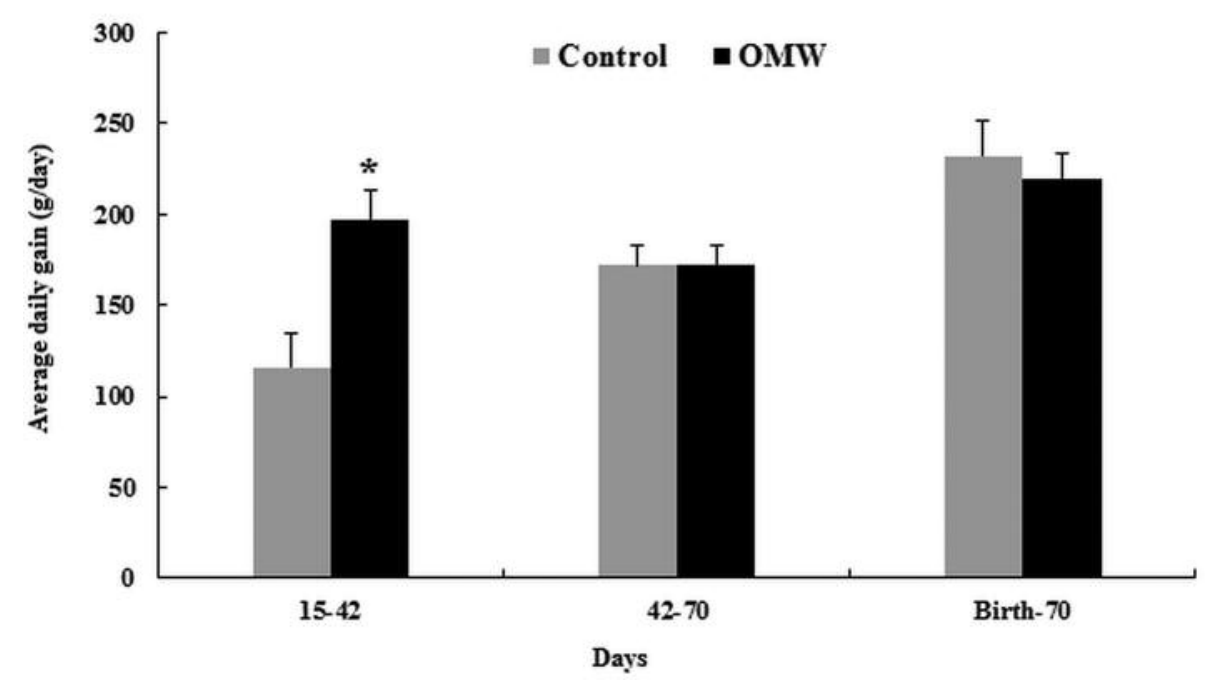

Figure 2. Effects on average daily gain in growing lambs after administration of control and feed supplemented with olive oil mill wastewater $(O M W)$. *Significantly different from the control group at the same sampling time $(p<0.05)$.

Assessment of antioxidant activity of experimental feed. The antioxidant activity of each feed was evaluated according to two radical-scavenging assays, DPPH and ABTS (Figure 1). The results from both assays showed higher antioxidant activity of the feeds supplemented with OMW, both before and after weaning, by at least two-fold, compared to the control feed.

Animal growth performance. Feed supplemented with OMW significantly improved the ADG (Figure 2). Prior to the weaning period (i.e. days 15-42), ADG was increased in the OMW group by $70.2 \%$ compared to the control group. In the post-weaning period (i.e. days 42-70), no significant difference was observed in the ADG between the two groups. Overall (i.e. days 15-70), lamb body weight did not differ significantly between OMW and control groups (Figure 2).

Assessment of oxidative stress markers in lamb blood. All oxidative stress biomarkers measured in blood (both plasma and erythrocyte lysate), except catalase activity, indicated that feed enriched with OMW improved the redox status of lambs. Specifically, the GSH level in red blood cell lysate was significantly increased both at days 42 and 70 post-birth by 106.9 and $155.9 \%$ in the OMW group compared to the control group (Figure 3A).

Catalase activity in erythrocyte lysate did not differ significantly between the two groups at both these time points (Figure 3B).

Regarding TAC in plasma of lambs, it was significantly higher in the OMW group compared to the control group only at day 42 post-birth (by $10.1 \%$; Figure 4A).
The level of TBARS in plasma was significantly lower in the OMW group compared to the control group by $30.6 \%$ at day 42 , but there was no significant difference at day 70 between the two groups (Figure 4B).

Finally, there was a significant decrease in protein carbonyl level by $40.3 \%$ at day 70 in the OMW group compared to the control group (Figure 4C).

Assessment of oxidative stress markers in lamb tissues. The feed supplemented with OMW enhanced the antioxidant levels and improved the redox status in lambs in almost all the tested tissues. In particular, the administration of feed supplemented with OMW to young lambs significantly increased the GSH level in spleen and brain at day 42 by 110.0 and $36.9 \%$, respectively, compared to the control group (Figure 5A) and by 19.0. 101.5, 40.9, and $12.8 \%$ in heart, spleen, quadriceps muscle and brain, respectively, at day 70 (Figure 5A).

The rate of $\mathrm{H}_{2} \mathrm{O}_{2}$ decomposition was significantly increased only in heart at day 42 by $17.3 \%$, while at day 70 , there was a significant increase in heart, liver and quadriceps muscle by $53.1,7.9$, and $116.7 \%$ respectively in the OMW group compared to the control group (Figure $5 \mathrm{~B}$ ).

TAC was significantly increased only in brain at both day 42 and 70 , by 56.1 and $32.6 \%$ respectively (Figure 6A).

The level of TBARS was significantly lower in all tissues except brain at day 42 in the OMW group by 10.3, 35.2, 55.2 and $11.9 \%$ in heart, spleen, liver and quadriceps muscle, respectively, than in the control group (Figure 6B). At day 70 post birth TBARS was decreased only in brain tissue, by 
A

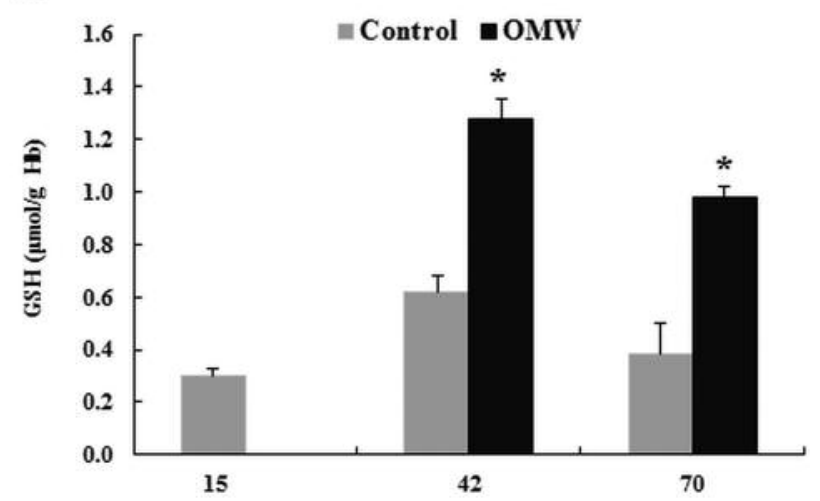

B

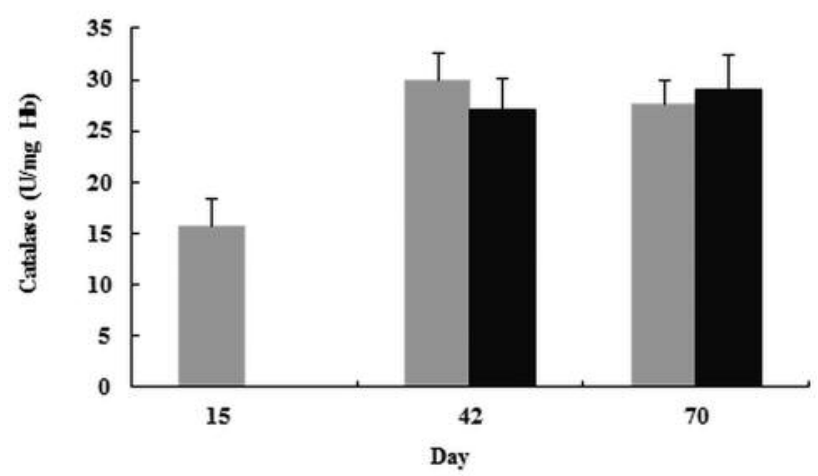

Figure 3. Effects on oxidative stress markers in red blood cell lysate. Glutathione (GSH) (A) level and catalase activity (B) in lamb erythrocytes after feeding with standard (control) and experimental (olive oil mill wastewater, OMW) feed at $15(n=4), 42(n=6$ from each group) and 70 ( $n=6$ from each group) days post birth. *Significantly different from the control group at the same sampling time $(p<0.05)$.

$52.0 \%$ in the OMW group compared to the control group (Figure 6B).

Finally, protein carbonyl levels were significantly decreased in heart, spleen and liver by $45.2,34.3$ and $50.1 \%$ respectively, at day 42 , while at day 70 , protein oxidation was lower by $20.3 \%$ only in quadriceps muscle in the OMW group compared to the controls (Figure 6C).

\section{Discussion}

OMW is a liquid of violet to dark brown color with a strong smell of olive oil (40). This byproduct is composed of vegetable water from the fruit and the water used in different stages of oil extraction that contains olive pulp, mucilage, pectin, oil, and other suspended components in a relatively stable emulsion (41). The composition and amounts of OMW cause serious environmental problems in areas of olive oil production, and the discharge of large quantities of

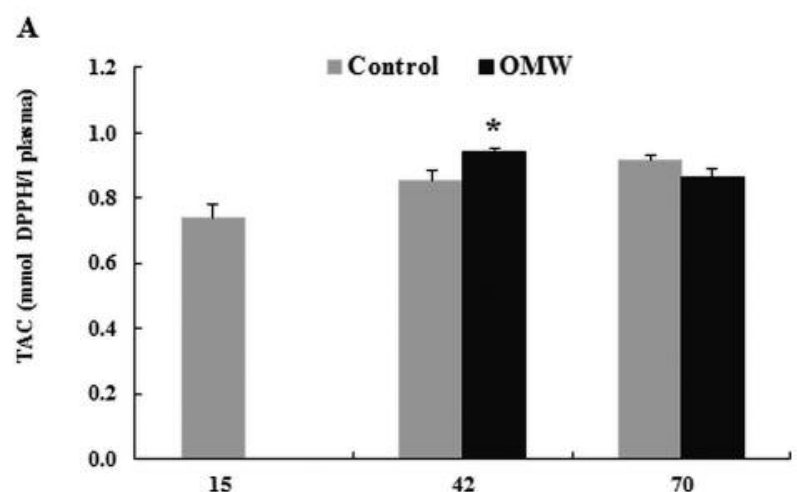

B

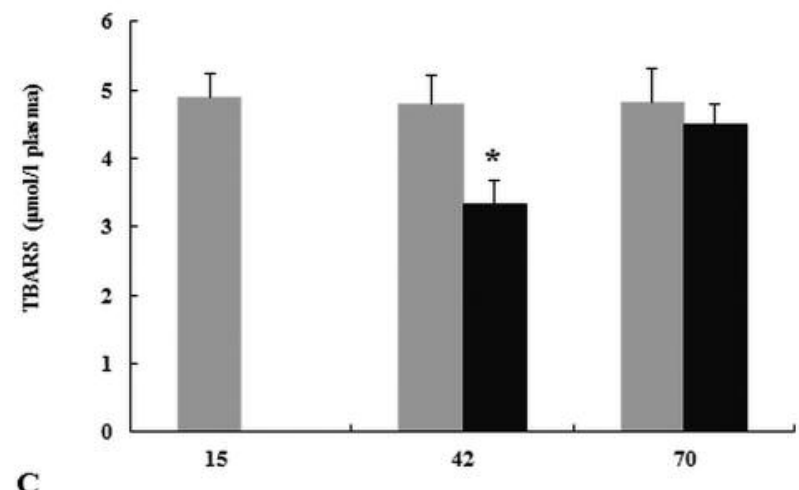

C

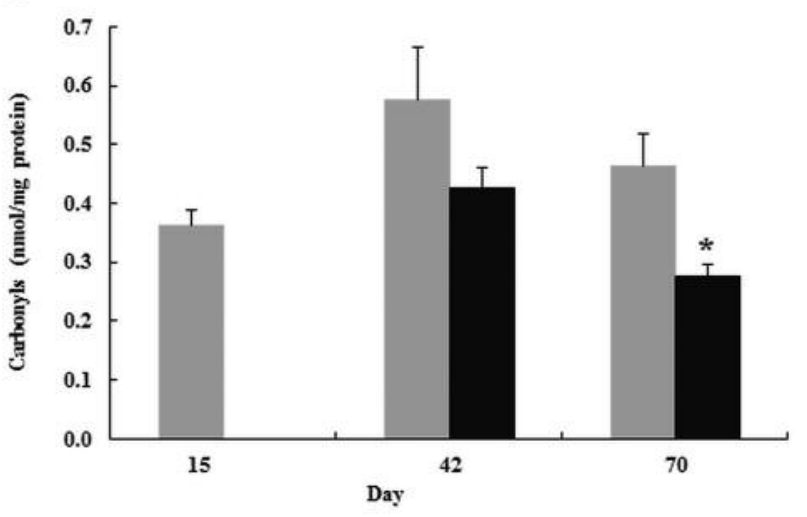

Figure 4. Effects on oxidative stress markers in plasma. Total antioxidant capacity (TAC) (A), thiobarbituric acid reactive species (TBARS) (B) and protein carbonyl level $(C)$ in lamb plasma after feeding with standard (control) and experimental (olive oil mill wastewater, OMW) feed at $15(n=4), 42(n=6$ from each group) and 70 $(n=6$ from each group) days post birth. *Significantly different from the values of control group at the same sampling time $(p<0.05)$.

these pollutants into the sewage system without any treatment is not possible. Different biological and chemical/physical methods have been proposed to reduce the organic matter and tannins present in OMW in order to reduce their effects on the environment. On the other hand, 


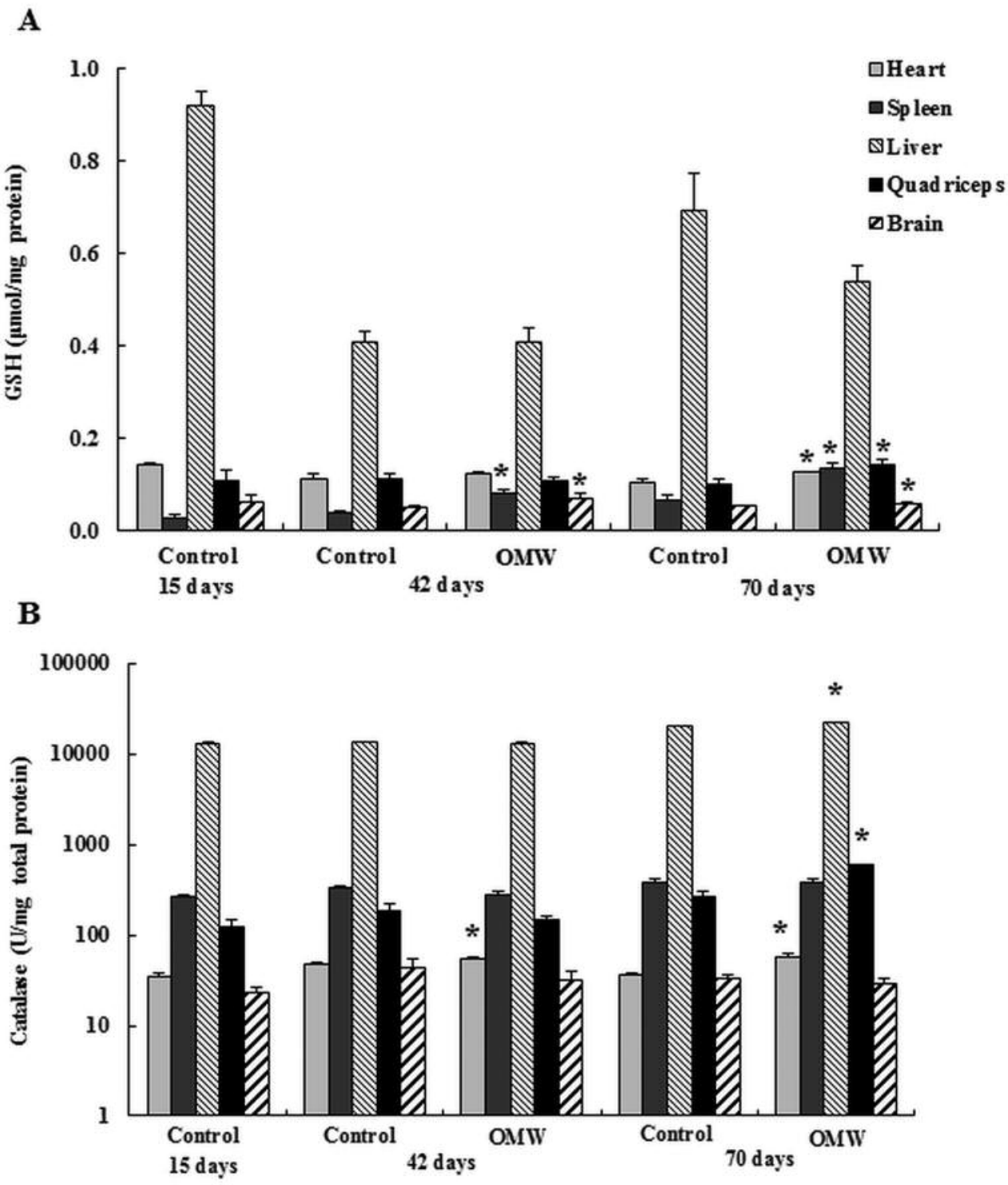

Figure 5. Effects on oxidative stress markers glutathione (GSH) (A) and catalase (B) in lamb tissues (heart, spleen, liver, quadriceps and brain) after feeding with standard (control) and experimental (olive oil mill wastewater, OMW) feed at $15(n=4), 42$ ( $n=6$ from each group) and 70 ( $n=6$ from each group) day post birth. *Significantly different from the control group at the same sampling time $(p<0.05)$.

phenolic extracts from OMW can be used as natural alternatives to commercial synthetic antioxidants with applications in food, as well as in the development of nutraceutical and medical products (8).

The aim of this study was to evaluate the effects of feed supplemented with OMW on the redox status of young lambs and to suggest a new method in order to reduce environmental pollution caused by the high organic matter of byproducts which are produced by olive oil industries. Both in vitro free radical-scavenging assays (i.e. DPPH and ABTS) showed that the feed supplemented with OMW had about 2-fold higher antioxidant activity than that of the control. This strong antioxidant activity of OMW byproducts may mainly be based on their high polyphenolic content (e.g. tyrosol, hydroxytyrosol, oleuropein, caffeic acid, vanillic acid, coumaric acid, ferulic acid, gallic acid, hydroxybenzoic acid, kaempherol, apigenin and quercetin) (8).

The findings showed that the feed supplemented with OMW increased animals' growth performance in the OMW group compared to controls, especially at a young age. According to Payne and Southern (42), ROS oxidize and damage cellular biological molecules, as a result causing a 

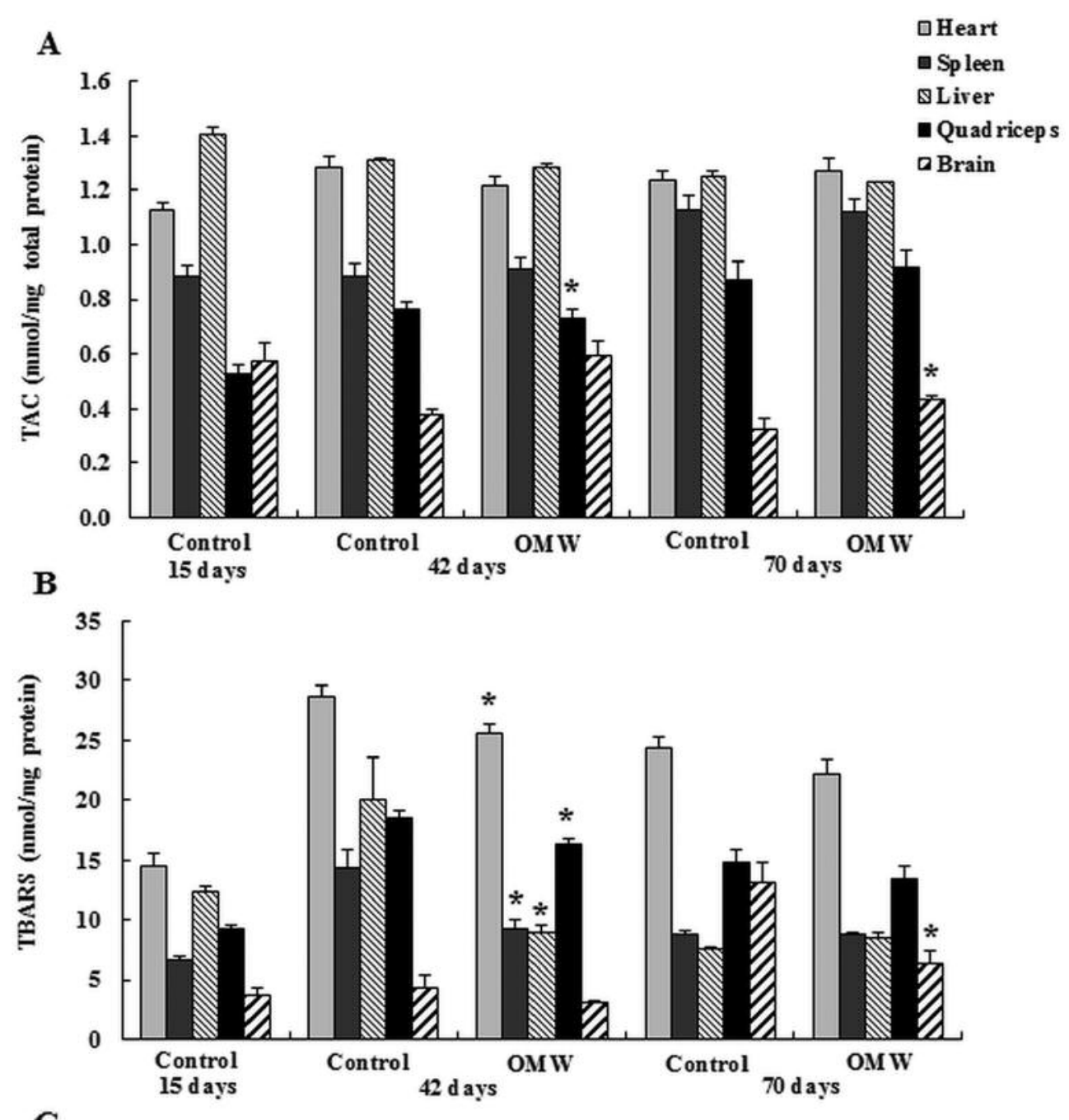

C

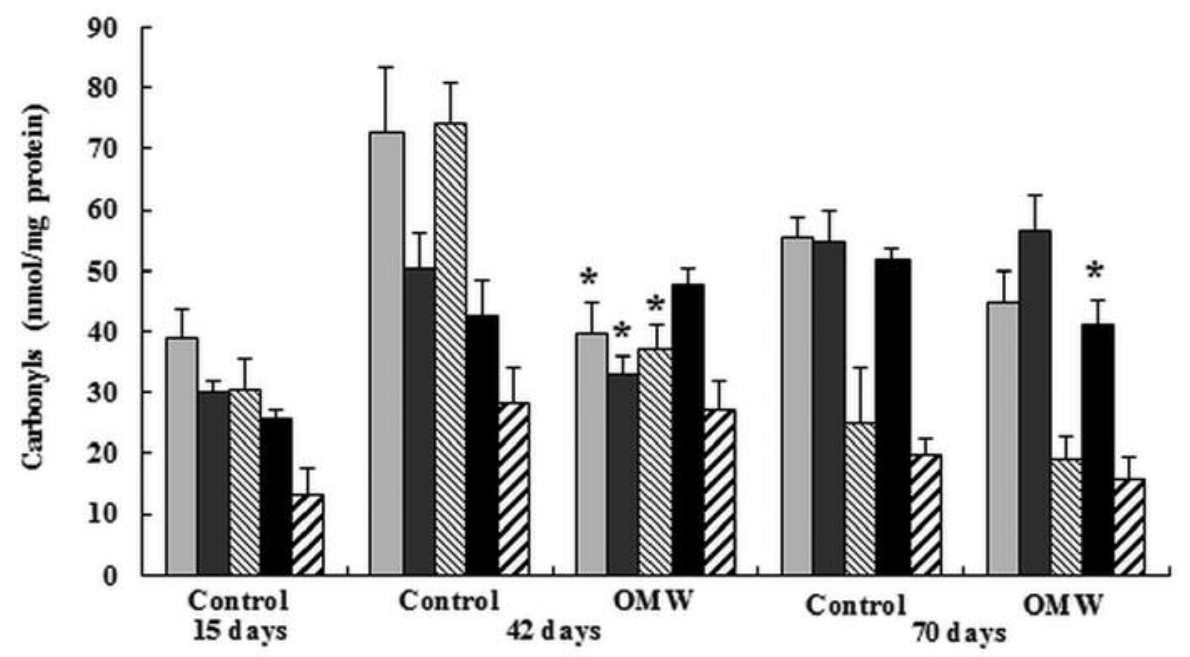

Figure 6. Effects on oxidative stress markers TAC (A), TBARS $(B)$ and protein carbonyl levels $(C)$ in lamb tissues (heart, spleen, liver, quadriceps and brain) after feeding with standard (control) and experimental (olive oil mill wastewater, OMW) feed at 15 ( $n=4), 42(n=6$ from each group) and 70 ( $n=6$ from each group) day post-birth. *Significantly different from the control group at the same sampling time $(p<0.05)$. 
variety of impairments to intestinal membrane integrity. Thus, the improvement in ADG and growth performance of lambs may be due to the experimental feed's antioxidant properties that resulted in ROS scavenging, reducing intestinal membrane damage, and consequently improving gut functionality.

Regarding the effects of the feed supplemented with OMW on the redox status of the Iambs, the results showed that the GSH level was significantly increased in spleen and brain tissues at day 42 post birth, in heart, spleen, quadriceps muscle and brain tissues at day 70 post birth and in erythrocytes at both sampling times in the OMW group compared to control group. Similarly, another study of our research group, showed that the administration of feed supplemented with polyphenols from OMW to piglets and broilers increased the GSH level in erythrocytes and different tissues $(10,28)$. Another study conducted on humans also showed that consumption of OMW extract increased plasma GSH (43). These results are of particular importance, since GSH, the most abundant non-protein thiol source in cells, is one of the major intracellular antioxidant molecules protecting against oxidative stress. The effect of feed supplemented with OMW on the GSH level may be explained through the modulation of the main enzymes responsible for GSH synthesis, such as GSH synthase and gammaglutamylcysteine synthase ( $\gamma$-GCL) (44). The regulation of the expression of the enzymes involved in GSH synthesis or metabolism is mainly mediated through the antioxidant response element, a cis-enhancer sequence regulating the transcription of various antioxidant genes (45). Interestingly, in another study, we showed that administration of feed supplemented with OMW to lambs increased the activity or expression of antioxidant enzymes regulated by the antioxidant response element (46). In addition, other studies have reported that the OMW-induced increase in GSH level might be due to antioxidant response element-mediated increase in $\gamma$-GCL and GSH synthetase expression $(43,46)$.

The conversion of $\mathrm{H}_{2} \mathrm{O}_{2}$ to $\mathrm{H}_{2} \mathrm{O}$ and $\mathrm{O}_{2}$ in erythrocytes is mainly attributed to catalase activity $(47,48)$. The results showed that catalase activity in erythrocytes was not significantly different between the OMW and control groups. The fact that polyphenols from OMW had no effect on the activity of catalase may be explained by their ability to enhance other antioxidant mechanisms, basically those associated with the GSH system. However, we and other researchers have reported that administration of polyphenolic extract from OMW increased catalase activity in erythrocytes and the rate of $\mathrm{H}_{2} \mathrm{O}_{2}$ decomposition in several tissues in rats, mice and piglets $(28,49,50)$. Thus, the effect of polyphenols from OMW on catalase may be animal-specific.

Unlike erythrocytes, the decomposition of $\mathrm{H}_{2} \mathrm{O}_{2}$ to $\mathrm{H}_{2} \mathrm{O}$ and $\mathrm{O}_{2}$ in tissues, is attributed not only to catalase but also to other enzymes such is glutathione peroxidase and peroxiredoxins (51). The rate of $\mathrm{H}_{2} \mathrm{O}_{2}$ decomposition was significantly higher in liver and brain at day 70 post birth and in heart at both day 42 and 70 post-birth in the OMW group compared to the control group. These results are very important since, if $\mathrm{H}_{2} \mathrm{O}_{2}$ is not decomposed to harmless products such as oxygen and water, in the presence of metal ions it may lead through the Haber-Weiss and Fenton reaction to the production of hydroxyl radicals (52). This is crucial for cells and tissues, because hydroxyl radicals can cause severe damage to macromolecules such as DNA, proteins and lipids $(53,54)$.

Apart from the enhancement of antioxidant mechanisms, the experimental feed reduced oxidative stress-induced damage such as lipid peroxidation. In biological systems, lipid peroxidation, generates a number of degradation products, such as MDA, and may lead to cell death $(55,56)$. TBARS in plasma, indicating lipid peroxidation, were significantly decreased at 42 days post-birth in the OMW group compared to the controls. This decrease in TBARS agreed with the corresponding increase in the antioxidant GSH at day 42. These findings are important, since animals at the young age of 42 days have weak antioxidant mechanisms, and so there is a great need for their enhancement $(19,32)$. Metcalfe and Alonso-Alvarez (57) have suggested that early development is a life stage where oxidative stress levels are high due to the presumed link between the high metabolic activities required for growth and ROS generation. Moreover, lipid oxidative damage was higher in lambs at a young age than in adults, and it was positively related to growth rate over the first 4 months of life (58). Moreover, feed supplemented with OMW reduced TBARS in heart, spleen, liver and quadriceps muscle at 42 days post-birth and in brain at 70 days compared to controls. Like in plasma, these results are also in accordance with the corresponding increase in GSH level in these tissues. In previous studies, we have shown that feed supplemented with polyphenols derived from OMW reduced lipid peroxidation in blood and tissues of different farm animals, such as chickens and piglets $(10,28)$. Major polyphenolics (e.g. tyrosol, hydroxytyrosol) found in OMW have been shown to be responsible for reduction of lipid peroxidation $(10,59)$. Lipid peroxidation, apart from affecting animal health, may reduce meat quality due to the production of offflavor products $(60,61)$. Thus, the decrease in TBARS 1 in muscle is of particular importance, because it is the main edible part from these animals.

Furthermore, the results showed that feed supplemented with OMW significantly reduced protein oxidation (i.e. protein carbonyl levels) in blood plasma at 70 day post-birth compared to control. In tissues, protein carbonyl levels were also decreased in heart, spleen and liver at day 42 post birth and in quadriceps muscle at day 70 post birth. Similar studies from our research group have shown that feed 
supplemented with OMW reduced these levels both in blood and many tissues of piglets and chickens $(10,28)$. Zhang et $a l$. have shown that protein oxidation can induce protein polymerization and aggregation, thus affecting their digestibility, which reduces the nutritional value of muscle foods (62). Moreover, they suggested that oxidation of essential amino acids of meat proteins (i.e. cysteine, tyrosine, glycine, histidine, alanine, leucine, lysine) could reduce its nutritional value (62). Thus, the decrease in protein carbonyl levels in quadriceps muscle, an edible tissue, indicates improvement of meat quality.

Finally, the TAC, indicating the total level of antioxidant molecules, was increased in blood significantly at day 42 post-birth in the OMW compared to the control group. This increase was in accordance with the simultaneous increase in GSH and decrease in lipid peroxidation. TAC in tissues of the OMW group did not differ significantly from those of control, apart from brain tissue in which it was increased both at day 42 and 70 post-birth. The increase in TAC in brain may be attributed to the parallel increase in GSH at the same timepoints. The absence of increase in TAC in other tissues of then OMW group, which did exhibit an increase in GSH, may be explained by the fact that when some antioxidants mechanisms are increased in living organisms, some others may be reduced as a compensatory mechanism $(21,32)$. On the other hand, a previous report of our research group showed high TAC in many tissues, and especially in brain, of animals who received feed supplemented with OMW polyphenols (28). Frankel et al. suggested that the increase in TAC levels in pigs after feeding with OMW was due to the direct free radical-scavenging from polyphenols. (8)

In conclusion, as far as we are aware, this is the first study showing that feed supplemented with OMW improved antioxidant mechanisms in lambs and reduced free radicals by reducing lipid and protein oxidation in blood and several vital organs. However, these beneficial effects seemed to be tissue-specific perhaps due to physiological and biochemical differences, as well as to differences in the content of antioxidant enzymes and molecules between different tissues (32). Moreover, an increase in GSH level of lamb blood and tissues seemed to be a main mechanism for the enhancement of antioxidant capacity. Thus, the exploitation of OMW from olive oil industries for making feed with antioxidant properties can be an alternative and costeffective intervention for the treatment of oxidative stressinduced pathological conditions in lambs. In addition, as mentioned above, OMW causes serious pollutant problems in olive oil production areas and its use for making livestock feed could be a way to protect the environment. Of course, more studies are needed in order to elucidate the molecular mechanisms through which the bioactive compounds of OMW enhance the antioxidant mechanisms and improve the animals' redox status.

\section{Conflicts of Interest}

The Authors declare that there are no conflicts of interest in regard to this study.

\section{References}

1 Michailides M, Panagopoulos P, Akratos CS, Tekerlekopoulou AG and Vayenas DV: A full-scale system for aerobic biological treatment of olive mill wastewater. J Chem Technol Biotechnol 86: 888-892, 2011.

2 Paraskeva P and Diamadopoulos E: Technologies for olive mill wastewater (OMW) treatment: a review. J Chem Technol Biotechnol 81: 1475-1485, 2006.

3 Pelendridou K, Michailides MK, Zagklis DP, Tekerlekopoulou AG, Paraskeva CA and Vayenas D V: Treatment of olive mill wastewater using a coagulation-flocculation process either as a single step or as post-treatment after aerobic biological treatment. J Chem Technol Biotechnol 89: 1866-1874, 2014.

4 Adhoum $\mathrm{N}$ and Monser L: Decolourization and removal of phenolic compounds from olive mill wastewater by electrocoagulation. Chem Eng Process Process Intensif 43: 1281-1287, 2004.

5 Rinaldi M, Rana G and Introna M: Olive-mill wastewater spreading in southern Italy: effects on a durum wheat crop. F Crop Res 84: 319-326, 2003.

6 Dordio A and Carvalho AJP: Constructed wetlands with light expanded clay aggregates for agricultural wastewater treatment. Sci Total Environ 463-464: 454-461, 2013.

7 Zagklis DP, Arvaniti EC, Papadakis VG and Paraskeva CA: Sustainability analysis and benchmarking of olive mill wastewater treatment methods. J Chem Technol Biotechnol 88 : 742-750, 2013.

8 Frankel E, Bakhouche A, Lozano-Sanchez J, Segura-Carretero A and Fernandez-Gutierrez A: Literature review on production process to obtain extra virgin olive oil enriched in bioactive compounds. Potential use of byproducts as alternative sources of polyphenols. J Agric Food Chem 61: 5179-5188, 2013.

9 Papadopoulou A, Petrotos K, Stagos D, Gerasopoulos K, Maimaris A, Makris H, Kafantaris I, Makri S, Kerasioti E, Halabalaki M, Brieudes V, Ntasi G, Kokkas S, Tzimas P, Goulas P, Zakharenko A, Golokhvast K, Tsatsakis A and Kouretas D: Enhancement of antioxidant mechanisms and reduction of oxidative stress in chickens after the administration of drinking water enriched with polyphenolic powder from olive mill waste waters. Oxid Med Cell Longev 2017: 8273160, 2017.

10 Gerasopoulos K, Stagos D, Kokkas S, Petrotos K, Kantas D, Goulas P and Kouretas D: Feed supplemented with byproducts from olive oil mill wastewater processing increases antioxidant capacity in broiler chickens. Food Chem Toxicol 82: 42-49, 2015.

11 Kris-Etherton PM, Hecker KD, Bonanome A, Coval SM, Binkoski AE, Hilpert KF, Griel AE and Etherton TD: Bioactive compounds in foods: their role in the prevention of cardiovascular disease and cancer. Am J Med 113(Suppl): 71S88S, 2002.

12 Banjari I, Misir A, Savikin K, Jokic S, Molnar M, De Zoysa HKS and Waisundara VY: Antidiabetic effects of Aronia melanocarpa and its other therapeutic properties. Front Nutr 4: $53,2017$. 
13 Gouvinhas I, Machado N, Sobreira C, Dominguez-Perles R, Gomes S, Rosa E and Barros AIRNA: Critical review on the significance of olive phytochemicals in plant physiology and human health. Molecules 22(11): pii: E1986 2017.

14 Lykkesfeldt $\mathrm{J}$ and Svendsen O: Oxidants and antioxidants in disease: oxidative stress in farm animals. Vet J 173: 502-511, 2007.

15 Lauritzen B, Lykkesfeldt J and Friis C: Evaluation of a single dose versus a divided dose regimen of danofloxacin in treatment of Actinobacillus pleuropneumoniae infection in pigs. Res Vet Sci 74: 271-277, 2003.

16 Miller J, Brzezinska-Slebodzinska $\mathrm{E}$ and Madsen F: Oxidativestress, antioxidants, andanimalfunction. J Dairy Science 76: 2812-2823, 1993.

17 Basu S and Eriksson M: Retinol palmitate counteracts oxidative injury during experimental septic shock. Ann Acad Med Singapore 30: 265-269, 2001.

18 Chaiyotwittayakun A, Erskine RJ, Bartlett PC, Herd TH, Sears PM and Harmont RJ: The effect of ascorbic acid and L-histidine therapy on acute mammary inflammation in dairy cattle. J Dairy Sci 85: 60-67, 2002.

19 Jain A and Flora SJS: Dose related effects of nicotine on oxidative injury in young, adult and old rats. J Environ Biol 33: 233-238, 2012.

20 Chan JKW, Charrier JG, Kodani SD, Vogel CF, Kado SY, Anderson DS, Anastasio C and Van Winkle LS: Combustionderived flame generated ultrafine soot generates reactive oxygen species and activates Nrf2 antioxidants differently in neonatal and adult rat lungs. Part Fibre Toxicol 10: 34, 2013.

21 Makri S, Kafantaris I, Stagos D, Chamokeridou T, Petrotos K, Gerasopoulos K, Mpesios A, Goutzourelas N, Kokkas S, Goulas P, Komiotis D and Kouretas D: Novel feed including bioactive compounds from winery wastes improved broilers' redox status in blood and tissues of vital organs. Food Chem Toxicol 102: 24-31, 2017.

22 Yamada K, Ogawa H, Hara A, Yoshida Y, Yonezawa Y, Karibe K, Nghia VB, Yoshimura H, Yamamoto Y, Yamada M, Nakamura K and Imai K: Mechanism of the antiviral effect of hydroxytyrosol on influenza virus appears to involve morphological change of the virus. Antiviral Res 83: 35-44, 2009.

23 Castaner O, Fito M, Lopez-Sabater MC, Poulsen HE, Nyyssonen K, Schroder H, Salonen JT, De la Torre-Carbot K, Zunft H-F, De la Torre R, Baumler H, Gaddi A V, Saez GT, Tomas M and Covas MI: The effect of olive oil polyphenols on antibodies against oxidized LDL. A randomized clinical trial. Clin Nutr 30: 490-493, 2011.

24 Giacosa A, Barale R, Bavaresco L, Gatenby P, Gerbi V, Janssens J, Johnston B, Kas K, La Vecchia C, Mainguet P, Morazzoni P, Negri E, Pelucchi C, Pezzotti M and Rondanelli M: Cancer prevention in Europe: the Mediterranean diet as a protective choice. Eur J Cancer Prev 22: 90-95, 2013.

25 Kalogerakis N, Politi M, Foteinis S, Chatzisymeon E and Mantzavinos D: Recovery of antioxidants from olive mill wastewaters: a viable solution that promotes their overall sustainable management. J Environ Manage 128: 749-758, 2013

26 Paiva-Martins F, Fernandes J, Rocha S, Nascimento H, Vitorino R, Amado F, Borges F, Belo L and Santos-Silva A: Effects of olive oil polyphenols on erythrocyte oxidative damage. Mol Nutr Food Res 53: 609-616, 2009.

27 Cicerale S, Lucas L and Keast R: Biological activities of phenolic compounds present in virgin olive oil. Int J Mol Sci 11: 458-479, 2010.
28 Gerasopoulos K, Stagos D, Petrotos K, Kokkas S, Kantas D, Goulas $\mathrm{P}$ and Kouretas D: Feed supplemented with polyphenolic byproduct from olive mill wastewater processing improves the redox status in blood and tissues of piglets. Food Chem Toxicol 86: 319-327, 2015.

29 Skoulikidis N, Dimitriou E and Karaouzas I: The Rivers of Greece: Evolution, Current Status and Perspectives. Springer, 2017.

30 Mekki A, Dhouib A and Sayadi S: Review: Effects of olive mill wastewater application on soil properties and plants growth. Int J Recycl Org Waste Agric 2: 15, 2013.

31 Singleton VL, Orthofer R and Lamuela-Raventos RM: Analysis of total phenols and other oxidation substrates and antioxidants by means of folin-ciocalteu reagent. Methods Enzymol 299: 152-178, 1998.

32 Kafantaris I, Kotsampasi B, Christodoulou V, Kokka E, Kouka P, Terzopoulou Z, Gerasopoulos K, Stagos D, Mitsagga C, Giavasis I, Makri S, Petrotos K and Kouretas D: Grape pomace improves antioxidant capacity and faecal microflora of lambs. J Anim Physiol Anim Nutr 101(5): e108-e121, 2017.

33 Brand-Williams W, Cuvelier ME and Berset C: Use of a free radical method to evaluate antioxidant activity. LWT - Food Sci Technol 28: 25-30, 1995.

34 Cano A, Hernández-Ruíz J, García-Cánovas F, Acosta M and Arnao MB: An end-point method for estimation of the total antioxidant activity in plant material. Phytochem Anal 9: 196202, 1998.

35 Reddy YN, Murthy S V, Krishna DR and Prabhakar MC: Role of free radicals and antioxidants in tuberculosis patients. Indian J Tuberc 51: 213-218, 2004.

36 Aebi H: Catalase in vitro. Methods Enzymol 105: 121-126, 1984. 37 Patsoukis N, Zervoudakis G, Panagopoulos NT, Georgiou CD, Angelatou F and Matsokis NA: Thiol redox state (TRS) and oxidative stress in the mouse hippocampus after pentylenetetrazol-induced epileptic seizure. Neurosci Lett 357: 83-86, 2004.

38 Keles MS, Taysi S, Sen N, Aksoy H and Akcay F: Effect of corticosteroid therapy on serum and CSF malondialdehyde and antioxidant proteins in multiple sclerosis. Can J Neurol Sci 28: 141-143, 2001.

39 Janaszewska A and Bartosz G: Assay of total antioxidant capacity: comparison of four methods as applied to human blood plasma. Scand J Clin Lab Invest 62: 231-236, 2002.

40 Pierantozzi P, Zampini C, Torres M, Isla MI, Verdenelli RA, Meriles JM and Maestri D: Physico-chemical and toxicological assessment of liquid wastes from olive processing-related industries. J Sci Food Agric 92: 216-223, 2012.

41 Paredes C, Cegarra J, Roig A, Sánchez-Monedero MA and Bernal MP: Characterization of olive mill wastewater (alpechin) and its sludge for agricultural purposes. Bioresour Technol 67: 111-115, 1999.

42 Payne RL and Southern LL: Changes in glutathione peroxidase and tissue selenium concentrations of broilers after consuming a diet adequate in selenium. Poult Sci 84: 1268-1276, 2005.

43 Visioli F, Wolfram R, Richard D, Abdullah MICB and Crea R: Olive phenolics increase glutathione levels in healthy volunteers. J Agric Food Chem 57: 1793-1796, 2009.

44 Aquilano K, Baldelli S and Ciriolo MR: Glutathione: new roles in redox signaling for an old antioxidant. Front Pharmacol 5: 196, 2014.

45 Kumar H, Kim I-S, More SV, Kim B-W and Choi D-K: Natural product-derived pharmacological modulators of Nrf2/ARE pathway for chronic diseases. Nat Prod Rep 31: 109-139, 2014. 
46 Kerasioti E, Terzopoulou Z, Komini O, Kafantaris I, Makri S, Stagos D, Gerasopoulos K, Anisimov NY, Tsatsakis AM and Kouretas D: Tissue specific effects of feeds supplemented with grape pomace or olive oil mill wastewater on detoxification enzymes in sheep. Toxicol Reports 4: 364-372, 2017.

47 Agar NS, Sadrzadeh SM, Hallaway PE and Eaton JW: Erythrocyte catalase. A somatic oxidant defense? J Clin Invest 77: 319-321, 1986.

48 Scott MD, Lubin BH, Zuo L and Kuypers FA: Erythrocyte defense against hydrogen peroxide: preeminent importance of catalase. J Lab Clin Med 118: 7-16, 1991

49 Hamden K, Allouche N, Damak M and Elfeki A: Hypoglycemic and antioxidant effects of phenolic extracts and purified hydroxytyrosol from olive mill waste in vitro and in rats. Chem Biol Interact 180: 421-432, 2009.

50 Fki I, Sahnoun Z and Sayadi S: Hypocholesterolemic effects of phenolic extracts and purified hydroxytyrosol recovered from olive mill wastewater in rats fed a cholesterol-rich diet. J Agric Food Chem 55: 624-631, 2007.

51 Halliwell B, Clement M V and Long LH: Hydrogen peroxide in the human body. FEBS Lett 486: 10-13, 2000.

52 Lipinski B: Hydroxyl Radical and Its Scavengers in Health and Disease. Oxid Med Cell Longev 2011: 809696, 2011.

53 Phaniendra A, Jestadi DB and Periyasamy L: Free radicals: properties, sources, targets, and their implication in various diseases. Indian J Clin Biochem 30: 11-26, 2015.

54 Birben E, Sahiner UM, Sackesen C, Erzurum S and Kalayci O: Oxidative Stress and Antioxidant Defense. World Allergy Organ J 5: 9-19, 2012.

55 El-Abbassi A, Kiai $\mathrm{H}$ and Hafidi A: Phenolic profile and antioxidant activities of olive mill wastewater. Food Chem 132: 406-412, 2012.
56 Mylonas C and Kouretas D: Lipid peroxidation and tissue damage. In Vivo 13: 295-309, 1999.

57 Metcalfe NB and Alonso-Alvarez C: Oxidative stress as a lifehistory constraint: the role of reactive oxygen species in shaping phenotypes from conception to death. Funct Ecol 24: 984-996, 2010.

58 Nussey DH, Pemberton JM, Pilkington JG and Blount JD: Life history correlates of oxidative damage in a free-living mammal population. Funct Ecol 23: 809-817, 2009.

59 Rubio-Senent F, de Roos B, Duthie G, Fernandez-Bolanos J and Rodriguez-Gutierrez G: Inhibitory and synergistic effects of natural olive phenols on human platelet aggregation and lipid peroxidation of microsomes from vitamin E-deficient rats. Eur J Nutr 54: 1287-1295, 2015.

60 Arshad MS, Anjum FM, Khan MI, Shahid M, Akhtar S and Sohaib M: Wheat germ oil enrichment in broiler feed with $\alpha$ lipoic acid to enhance the antioxidant potential and lipid stability of meat. Lipids Health Dis 12: 164, 2013.

61 Nam KC and Ahn DU: Use of antioxidants to reduce lipid oxidation and off, Odor volatiles of irradiated pork homogenates and patties. Meat Sci 63: 1-8, 2003.

62 Zhang W, Xiao S and Ahn DU: Protein oxidation: basic principles and implications for meat quality. Crit Rev Food Sci Nutr 53: 1191-1201, 2013. 